\title{
Characterization of thirteen new polymorphic microsatellite markers from the honeycomb grouper Epinephelus merra
}

\author{
Delphine Muths ${ }^{\mathrm{a},{ }^{*}}$ and Jérôme Bourjea ${ }^{\mathrm{a}}$
}

\author{
a IFREMER Délégation Réunion, Rue Jean Bertho, BP60, 97822 Le Port, France \\ *: Corresponding author : Delphine Muths, email address : muthsdelphine@yahoo.fr
}

\begin{abstract}
:
Epinephelus merra (Serranidae) is the most common and widespread species of this genus, mostly found in reef habitats from South Africa to Central Pacific. Thirteen polymorphic microsatellite loci were isolated and characterized from this species. Polymorphism was studied in two localities from the Comoros archipelago-Mohéli and Moroni. Allelic diversity was 7.5, polymorphism ranging from 3 to 13 alleles. Overall heterozygosity was high with an average observed heterozygosity of 0.587 . Three of these loci were characterised by heterozygote deficiencies for both populations. Finally, ten of the 13 developed primers could be used in future population genetics study of E.merra that might be useful in a context of marine biodiversity conservation.
\end{abstract}

Keywords: Microsatellite - Epinephelus merra - Reef fish - Indian ocean 


\section{Introduction}

Groupers (Serranidae) are among the most abundant group of tropical marine fish (Randall \& Heemstra 1991). A total of 332 species of groupers species inhabit the Indo-Pacific region (Randall \& Heemstra 1991) with many being listed as critically endangered or threatened (Morris et al. 2000). The honeycomb grouper Epinephelus merra (Bloch 1793) is the most common and widespread species of this genus (Heemstra \& Randall 1993). E. merra is mostly found in sheltered marine habitats such as lagoon and bays, from South Africa to Central Pacific (Randall \& Heemstra 1991). E. merra is important in artisanal fisheries as food resource for many local communities (Heemstra \& Randall 1993). Its wide-ranging distribution, its abundance and its fishing interest (and in extenso easy accessability of samples) make this species a good model for reef fish connectivity study. Existing microsatellite primers for groupers have been successfully tested on 16 grouper species (Ramirez et al. 2006) but when used on E. merra from West Indian Ocean, only two of the eight potential primer pairs gave satisfactory and reliable amplifications. This study aims so to characterize new microsatellite markers from the reef fish $E$. merra to enable future population genetic studies.

\section{Methods}

Total genomic DNA was isolated from a single fish using Qiagen DNeasy spin columns and sent to GenoScreen, France (www.genoscreen.fr). $1 \mu \mathrm{g}$ was used for the development of microsatellites libraries through 454 GS-FLX Titanium pyrosequencing of enriched DNA libraries as described in Malausa et al. (in press). Briefly, total DNA was enriched for AG, AC, AAC, AAG, AGG, ACG, ACAT and ATCT repeat motifs and subsequently amplified. PCR products were purified, quantified and GsFLX librairies were then carried out following manufacturer's protocols (Roche Diagnostics) and sequenced on a GsFLX-PTP. This technique allowed the identification of 2909 potential markers. The bioinformatics program QDD (Meglécz et al. in press) was used to filter for redundancy resulting in a final set of sequences for which it was able to design primers. Tetra-repeats were favored in order to reduce the presence of stutter bands and increase the chance of accurate scoring. Finally 70 validated sets of primers were designed and tested for amplification. Primer sets were discarded if they failed to amplify or lead to multiple fragments. At the end, 15 tetranucleotide microsatellites were tested for polymorphism.

PCR amplifications were performed in $20 \mu \mathrm{L}$ reactions containing $25 \mathrm{ng}$ of template DNA, $1 \mathrm{x}$ reaction buffer, $1.5 \mathrm{mM} \mathrm{MgCl} 2,0.1 \mathrm{mM} \mathrm{dNTP}, 0.1 \mu \mathrm{M}$ fluorescent primer, $0.1 \mu \mathrm{M}$ primer, and $1 \mathrm{U}$ Taq polymerase. The PCR cycling consisted of an initial denaturation at $95^{\circ} \mathrm{C}$ for 5 minutes, followed by 35 cycles: denaturation at $95^{\circ} \mathrm{C}$ for 30 seconds, annealing at the appropriate temperature (Table 1) for 30 seconds, and extension at $72^{\circ} \mathrm{C}$ for 1 minute and a final extension at $72^{\circ} \mathrm{C}$ for 20 minutes. Each microsatellite amplification was diluted with $\mathrm{nH}_{2} \mathrm{O}$ (1:20), mixed with Formamide and LIZ 500 size standard (Applied Biosystems). Fragments were separated using an Applied Biosystems 3100 DNA Analyzer. Alleles were scored using GeneMapper® v 4.0 (Applied Biosystems). GenAlEx v6 (Peakall \& Smouse 2006) and Arlequin v 3.5.1.2 (Excoffier \& Lischer 2010) were used to estimate diversities and expected and observed heterozygosities (He and Ho, respectively) and to test HardyWeinberg equilibrium (HWE).

Two out of 15 microsatellites studied were found to be monomorphic and were removed from the analysis. Table 1 summarizes the characteristics of the 13 primer pairs of polymorphic loci developed from the reef fish E. merra. Samples from Mohéli $\left(12^{\circ} 24^{\prime} 10 \mathrm{~S} ; 43^{\circ} 41^{\prime} 31 \mathrm{E}\right)$ and Moroni ( $\left.11^{\circ} 47^{\prime} 10 \mathrm{~S} ; 4^{\circ} 14^{\prime} 55 \mathrm{E}\right)$ - Comoros archipelago - were genetotype using the 13 developed primers. Upon the 60 samples collected (30 in each site) and analysed, the number of alleles ranged from 3 to 13 per locus with a mean of $7.5( \pm 3.4)$. Observed and expected heterozygosities ( $\mathrm{Ho}$ and $\mathrm{He}$ ) as well as fixation indices (Fis) are shown in Table 1. Three of the 13 loci failed to meet HWE for both populations. All deviations from HWE were 
due to heterozygote deficiencies. These deficiencies might not be due to null alleles as amplifications succeed at more than $99.9 \%$. Therefore we suggest to consider with caution these loci and especially the locus Epi-53 in future studies. Finally, ten of these 13 primers could be used in future population genetics study of E.merra and could be useful in a context of marine biodiversity conservation.

\section{Acknowledgments}

This research was supported by European Funds - the European Cooperation Funds EU POCT-OI 2007-2013 (project CAMP) and the EU $7^{\text {th }}$ Funding Program - Capacities, Research Potential (project RUNSeaSciences) -, the French State (DIREN), La Réunion Council (Région Réunion) and a MASMA grant of the WIOMSA. We acknowledge the authorities of Comoros for allowing our sample collection. We are indebted to Stephanie Ferreira and Stéphanie Duthoy from GenoScreen, France (www.genoscreen.fr) for their work and their permanent help.

\section{References}

Excoffier L, Lischer H (2010) Arlequin suite ver 3.5: A new series of programs to perform population genetics analyses under Linux and Windows. Mol Ecol Res, 10, 564-567.

Heemstra PC, Randall JE (1993) Groupers of the World (Family Serranidae, Subfamily Epinephelinae). An annotated and illustrated catalogue of the grouper, rockcod, hind, coral grouper and lyretail species known to date. FAO Fisheries Synopsis, No. 125, Vol16, 382pp. Malausa T, Gilles A, Meglecz E, Blanquart H, Duthoy S, Costedoat C, Dubut V, Pech N, Castagnone-Sereno P, Delye C, Feau N, Frey P, Gauthier P, Guillemaud T, Hazard L, Le Corre V, Lung-Escarmant B, Male P, Ferreira S, Martin J (in press) High-throughput microsatellite isolation through 454 GS-FLX Titanium pyrosequencing of enriched DNA libraries. Mol Ecol Res.

Meglécz E, Costedoat C, Dubut V, Gilles A, Malausa T, Pech N, Martin J-F (in press) QDD: a user-friendly program to select microsatellite markers and design primers from large sequencing projects. Bioinformatics, 26, 403-404.

Morris A, Roberts C, Hawkins J (2000) The threatened status of groupers (Epinephelinae). Biodiversity and Conservation, 9, 919-942.

Peakall R, Smouse P (2006) GenAlEx 6: genetic analysis in Excel. Population genetic software for teaching and research. Mol Ecol Notes, 6, 288-295.

Ramirez MA, Acevedo JP, Planas S, Carlin JL, Funk SM, McMillan WO (2006) New microsatellite resources for groupers (Serranidae). Mol Ecol Notes, 6, 813-817.

Randall JE, Heemstra PC (1991) Revision of Indo-Pacific groupers (Perciformes: Serranidae: Epinephelinae), with descriptions of five new species. Indo-Pacific Fishes, 20, 1-332. 


\section{Tables}

\section{Table 1 Characterization of 13 microsatellite loci for Epinephelus merra}

with respectively $\mathrm{Na}$, $\mathrm{Ho}$ and $\mathrm{He}$, number of alleles, observed and expected heterozygosities at the population level; Fis, fixation index and test for deviation from Hardy-Weinberg expectations (ns $=$ non significant; ${ }^{*} p<0.05,{ }^{* \star *} p<0.01$ ) 


\begin{tabular}{|c|c|c|c|c|c|c|c|c|c|c|c|c|c|c|c|}
\hline \multirow{2}{*}{ Locus } & \multirow{2}{*}{ Primer sequence (5' to $\left.3^{\prime}\right)$} & \multirow{2}{*}{$\begin{array}{c}\text { Genbank } \\
\text { accession } \\
\text { number }\end{array}$} & \multirow{2}{*}{$\begin{array}{l}\text { Annealing } \\
\text { temperature }\end{array}$} & \multirow{2}{*}{$\begin{array}{l}\text { Repeat } \\
\text { motif }\end{array}$} & \multirow{2}{*}{$\begin{array}{c}\text { Range } \\
\text { size } \\
\text { (bp) }\end{array}$} & \multicolumn{5}{|c|}{ Mohéli $(n=30)$} & \multicolumn{5}{|c|}{ Moroni $(n=30)$} \\
\hline & & & & & & $\mathrm{Na}$ & Ho & $\mathrm{He}$ & Fis & $\mathbf{p}$ & $\mathrm{Na}$ & Ho & $\mathrm{He}$ & Fis & $\mathbf{p}$ \\
\hline \multirow[t]{2}{*}{ EPI-04 } & CTGGTAGGACTGAGTGTCCTGA & JF429839 & $60^{\circ} \mathrm{C}$ & AGAC & $90-134$ & 7 & 0.433 & 0.767 & 0.435 & $\star * \star$ & 10 & 0.733 & 0.805 & 0.089 & ns \\
\hline & CCATTAACTGCCACTGGACC & & & & & & & & & & & & & & \\
\hline \multirow[t]{2}{*}{ EPI-05 } & CATTCCTTCATGTTGTGAATGAC & JF429840 & $60^{\circ} \mathrm{C}$ & CTAT & & 11 & 0.666 & 0.863 & 0.228 & ns & 12 & 0.833 & 0.877 & 0.050 & ns \\
\hline & GGGATTATGTGCTGGCCTAT & & & & 3 & & & & & & & & & & \\
\hline \multirow[t]{2}{*}{ EPI-07 } & AATTCCCTTGAGGCGTTCTT & JF429841 & $60^{\circ} \mathrm{C}$ & GGAT & & 5 & 0.7 & 0.571 & -0.225 & ns & 5 & 0.633 & 0.626 & -0.011 & ns \\
\hline & TTTATGCTGTCGGGTTCTCC & & & & & & & & & & & & & & \\
\hline \multirow[t]{2}{*}{ EPI-08 } & ATGAGAAGAGGGAAGCGGAT & JF429842 & $60^{\circ} \mathrm{C}$ & TGGA & $111-127$ & 6 & 0.666 & 0.689 & 0.033 & ns & 6 & 0.733 & 0.682 & -0.074 & ns \\
\hline & CTGCGTGGAGAAAGTGTGAA & & & & $\perp \perp \perp-\perp<1$ & & & & & & & & & & \\
\hline \multirow[t]{2}{*}{ EPI-12 } & ATCCACCCATCTAGCTGACC & JF429843 & $60^{\circ} \mathrm{C}$ & ATCC & 45 & 3 & 0.4 & 0.439 & 0.089 & ns & 3 & 0.533 & 0.531 & -0.004 & ns \\
\hline & AATGGATCGGAAATTGCTTG & & & & & & & & & & & & & & \\
\hline \multirow[t]{2}{*}{ EPI-13 } & TGATTTGTCGAGGTAGGAGGA & JF429844 & $55^{\circ} \mathrm{C}$ & AATG & 25 & 5 & 0.7 & 0.721 & 0.030 & ns & 5 & 0.566 & 0.561 & -0.008 & ns \\
\hline & TTGACCAGCTGCTTTCTAAATG & & & & & & & & & & & & & & \\
\hline \multirow[t]{2}{*}{ EPI-16 } & CCCTGGGTGCTCTTAGTGTC & JF429845 & $60^{\circ} \mathrm{C}$ & CTAT & $131-157$ & 6 & 0.5 & 0.680 & 0.265 & * & 6 & 0.266 & 0.706 & 0.622 & *** \\
\hline & TGCACGTTCAAAGTGGCTAA & & & & & & & & & & & & & & \\
\hline \multirow[t]{2}{*}{ EPI-27 } & TGTCCTCAGATAATGACTGAAACTG & JF429846 & $60^{\circ} \mathrm{C}$ & GATA & $19-173$ & 12 & 0.666 & 0.848 & 0.214 & ns & 13 & 0.666 & 0.873 & 0.237 & ns \\
\hline & TTTGTACGAGCAATAATGGCA & & & & & & & & & & & & & & \\
\hline \multirow[t]{2}{*}{ EPI-35 } & GGTGCTTATTTGTGCCAGGT & JF429847 & $60^{\circ} \mathrm{C}$ & ATGG & 157 & 3 & 0.333 & 0.412 & 0.192 & ns & 3 & 0.466 & 0.586 & 0.204 & ns \\
\hline & AGCCATTCCTCAGCTCATTG & & & & & & & & & & & & & & \\
\hline \multirow[t]{2}{*}{ EPI-48 } & GGCCTACTGCAGAAGCTGTT & JF429848 & $58^{\circ} \mathrm{C}$ & GTCT & & 7 & 0.633 & 0.783 & 0.192 & $\star *$ & 6 & 0.566 & 0.732 & 0.226 & ns \\
\hline & AGCTACTTGCTCGGACCACA & & & & & & & & & & & & & & \\
\hline \multirow[t]{2}{*}{ EPI-49 } & TTTGTCATGCAGGATTGTCC & JF429849 & $60^{\circ} \mathrm{C}$ & ATCT & $131-198$ & 12 & 0.866 & 0.883 & 0.018 & ns & 13 & 0.8 & 0.866 & 0.076 & ns \\
\hline & CAAACTAGAGTATACCAGTCTGCCA & & & & 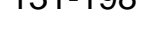 & & & & & & & & & & \\
\hline \multirow[t]{2}{*}{ EPI-50 } & TCTCСTTGACTTCССTGCAC & JF429850 & $58^{\circ} \mathrm{C}$ & CAGA & $170-198$ & 8 & 0.5 & 0.773 & 0.353 & 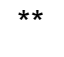 & 6 & 0.366 & 0.776 & 0.527 & ** \\
\hline & GCCTCATTTATTATTCTCTGCATGT & & & & & & & & & & & & & & \\
\hline \multirow[t]{2}{*}{ EPI-53 } & ACTGCAGCTCCTTGGTGACT & JF429851 & $60^{\circ} \mathrm{C}$ & ATCT & $80-240$ & 11 & 0.566 & 0.886 & 0.360 & $* \star *$ & 11 & 0.466 & 0.874 & 0.466 & $* * *$ \\
\hline & ACATTATGATTCTTCCTGTAGGG & & & & & & & & & & & & & & \\
\hline
\end{tabular}

